\title{
ГУМОРАЛЬНЫЙ ОТВЕТ НА ВИРУС ЭПШТЕЙНА-БАРР ПРИ АЛЛЕРГИИ
}

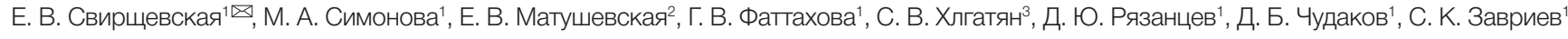
${ }^{1}$ Институт биоорганической химии имени М. М. Шемякина и Ю. А. Овчинникова, Москва, Россия

${ }^{2}$ Институт повышения квалификации Федерального медико-биологического агентства, Москва, Россия

${ }^{3}$ Научно-исследовательский институт вакцин и сывороток имени И. И. Мечникова, Москва, Россия

Аллергия I типа опосредована формированием IgЕ-антител к безвредным веществам. Механизмы возникновения аллергии остаются дискуссионными. Одним из факторов риска может быть снижение защитных функций барьерных тканей. Целью работы было проанализировать гуморальный иммунный ответ на вирус Эпштейна-Барр (ВЭБ) у больных с аллергией на гриб A. alternata и клещей домашней пыли D. farinae (КДП) и у здоровых людей. Известно, что до 90\% населения инфицированы ВЭБ. Инфицирование происходит в раннем возрасте параллельно с формированием аллергических реакций. Анализ антител проводили методом иммуно-ПЦР с использованием рекомбинантного белка ВЭБ rЕВNА1. Показали, что инфицирование как у больных, так и у доноров происходит в детстве; доля сероположительных по ВЭБ индивидов была сравнимой в группах (75 и $74 \%$ ). Доля пациентов с высокими титрами $\lg \mathrm{G}_{1}$ среди больных с аллергией была ниже (7\%) по сравнению с донорами (18\%), что соответствует меньшей вирусной нагрузке. У больных с аллергией, но не у здоровых людей, наблюдали снижение титров IgG, с возрастом ( $p=0,037)$. Кроме того, при аллергии повышены титры IgA, по сравнению с донорами, однако IgA -ответы при аллергии на гриб A. alternata и на КДП различались. При аллергии также раньше формировались IgM к ВЭБ. Таким образом, при аллергии быстрее формируется IgM и IgA, гуморальный ответ, что приводит к снижению с возрастом IgG, -титров.

Ключевые слова: аллергия, клещи домашней пыли, грибы A. alternata, рекомбинантные аллергены, вирус Эпштейна-Барр, иммуно-ПЦР

Информация о вкладе авторов: Е. В. Свирщевская - определение IgЕ титров на аллергены в сыворотках больных с аллергией и доноров, обработка данных, написание статьи; C. В. Хлгатян - подбор сывороток больных с аллергией и доноров различного возраста, типирование методом RIDA; Г. В. Фаттахова, Д. Б. Чудаков - определение IgЕ титров на аллергены в сыворотках больных с аллергией и доноров; Е. В. Матушевская - сбор сывороток больных с аллергией, обсуждение результатов и написание статьи; М. А. Симонова, Д. Ю. Рязанцев - постановка ПЦР; Д. Ю. Рязанцев - экспрессия в E. coli рекомбинантных белков ВЭБ, A. alternata и D. Farinae; Д. Ю. Чудаков - наработка, очистка и характеристика рекомбинантных белков; С. К. Завриев - оптимизация ПЦР, участие в обсуждении результатов.

Соблюдение этических стандартов: исследование одобрено этическим комитетом Института вакцин и сывороток им. И. И. Мечникова (протокол № 35 от 12 сентября 2018 г.).

Для корреспонденции: Елена Викторовна Свирщевская ул. Миклухо-Маклая, 16/10, г. Москва, 117997; esvir@mail.ibch.ru

Статья получена: 12.09.2018 Статья принята к печати: 15.02.2019 Опубликована онлайн: 01.03.2019

DOI: $10.24075 /$ vrgmu.2019.004

\section{HUMORAL RESPONSE TO EPSTEIN-BARR VIRAL INFECTION IN PATIENTS WITH ALLERGIES}

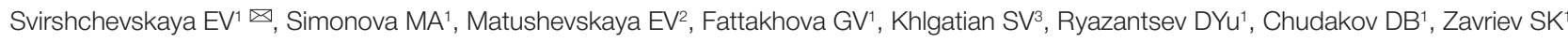

${ }^{1}$ Shemyakin-Ovchinnikov Institute of Bioorganic Chemistry, Moscow, Russia

${ }^{2}$ Institute of Continuing Vocational Education, Federal Medical Biological Agency, Moscow, Russia

${ }^{3}$ Mechnikov Research Institute of Vaccines and Sera, Moscow, Russia

Type I hypersensitivity is mediated by the production of IgE antibodies in response to normally harmless substances. Debate still continues about the mechanisms underlying allergic reactions. Reduced barrier tissue function can be one of the risk factors for allergies. The aim of the present work was to compare the humoral immune response to Epstein-Barr virus in patients allergic to the $A$. alternata fungus or $D$. farinae house dust mites and healthy donors. It is known that up to $90 \%$ of the world population are infected with EBV. This infection occurs at early age when a child develops allergy. The antibodies were analyzed using immuno-PCR and the recombinant EBV protein rEBNA. We were able to demonstrate that infection occurs at early age in both allergic patients and healthy donors. The proportion

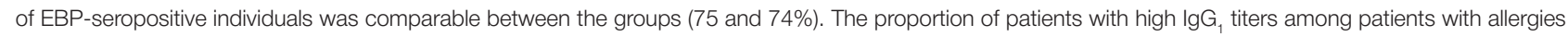

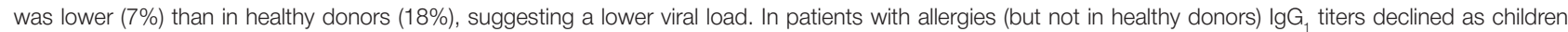
grew older $(p=0.037)$. Besides, IgA, titers were increased in patients with allergies in comparison with healthy donors, but differed between patients allergic to A. alternata and house dust mites. In allergic individuals, production of IgM against EBV was triggered earlier than in healthy donors. We conclude that IgM production and the $\lg _{1}$-mediated humoral response occur earlier in patients with allergies, causing a decline in $\lg _{1}$ titers over time.

Keywords: allergy, house dust mites, A. alternata, recombinant allergens, Epstein-Barr virus, immuno-PCR

Author contribution: Svirshchevskaya EV measured lgE titers against allergens in the sera of allergic individuals and healthy donors, processed the obtained data and participated in the writing of this article; Khlgatian SV selected sera samples for the study and conducted RIDA assays; Fattakhova GV and Chudakov DB measured IgE titers against allergens in the sera of patients with allergies and healthy donors; Matushevskaya EV collected sera samples from patients with allergies, participated in the discussion of the study results and in the writing of this article; Simonova MA and Ryazantsev DYu performed iPCR; Ryazantsev DYu expressed recombinant proteins of EBV, A. alternata and D. farinae; Chudakov DB synthesized, purified and characterized the sufficient amount of recombinant proteins for the study; Zavriev SK optimized PCR and participated in the discussion of the study results.

Compliance with ethical standards: the study was approved by the Ethics Committee of Mechnikov Research Institute of Vaccines and Sera (Protocol 35 dated September 12, 2018).

$\triangle$ Correspondence should be addressed: Elena V. Svirshchevskaya

Miklouho-Maclay 16/10, Moscow, 117997; esvir@mail.ibch.ru

Received: 12.09.2018 Accepted: 15.02.2019 Published online: 01.03.2019

DOI: 10.24075/brsmu.2019.004 
Вирус Эпштейна-Барр (ВЭБ) относится К ДНКсодержащим вирусам, входящим в семейство Herpesviridae и вызывающим у человека различные заболевания - от респираторных до онкологических. Известно 8 типов герпесвирусов, поражающих человека. Вирус простого герпеса 1-го и 2-го типов, варицелла-зостер (тип 3), ВЭБ (тип 4) и цитомегаловирус (тип 5) широко распространены в человеческой популяции. Инфицирование герпесвирусами типов 6 и 7 и ассоциированным с саркомой Капоши вирусом типа 8 встречается реже. Каждый взрослый человек инфицирован хотя бы одним типом герпесвируса, что диагностируют по наличию специфических антител в сыворотке крови. Так, 80-95\% людей - латентные носители ВЭБ и цитомегаловируса [1]. Латентная ВЭБинфекция ассоциирована с некоторыми онкологическими заболеваниями [1-3], рассеянным склерозом [4-5], системной красной волчанкой [6], отягощает течение вирусного иммунодефицита человека [7], провоцирует формирование аутоантител к ДНК и белкам человека [8-9]. Основные антигены ВЭБ - вирусный капсидный антиген, ранний антиген и ядерный антиген 1 (EBNA1) [10-11]. Белок EBNA1 необходим для латентной стадии персистенции вируса. Антитела G-класса вырабатываются против этого антигена каждый раз при реактивации вируса и отражают суммарную латентную вирусную нагрузку.

Инфицирование ВЭБ происходит контактным путем через поцелуи, общую посуду, предметы личной гигиены. Заражение воздушно-капельным путем также возможно, но встречается реже. Передача вируса может происходить от матери к ребенку во время вынашивания и родов, а также при грудном вскармливании. По данным различных исследований, у 50\% детей в возрасте до 3 лет выявляют антитела к ВЭБ [12-13]. Передача осуществляется, повидимому, через общую посуду и поцелуи.

Аллергия I типа характеризуется формированием гуморального lgЕ-опосредованного ответа на белки, входящие в состав безвредных микрочастиц - пыльцы, мертвых клещей домашней пыли, эпидермис домашних животных и др. [14-15]. Показано, что в коже и бронхиальном эпителии больных с аллергией имеются значительные отличия от здоровых барьерных тканей [16-17]. Целью данной работы была оценка гуморального ответа на ВЭБ у больных с аллергией на A. alternata и D. farinae.

Ранее нами был разработан метод анализа антител $\operatorname{lgG}_{1}$ к ВЭБ и $\operatorname{lgE}$ к различным аллергенам с помощью количественной полимеразной цепной реакции (ПЦР) [18-19]. Иммуно-ПЦР (иПЦР) является чувствительным методом, используемым для детекции антител в биологических жидкостях [20-21]. Среди преимуществ иПЦР - линейность дозовых кривых в широком диапазоне концентраций, что позволяет определять титры специфичных антител с помощью меньшего количества разведения сывороток [18-19].

\section{ПАЦИЕНТЫ И МЕТОДЫ}

\section{Сыворотки}

В работе использовали сыворотки детей и взрослых с гиперчувствительностью к клещам домашней пыли и грибу Alternaria alternata. Все сыворотки получены из КПО ФГБНУ НИИ вакцин и сывороток им. И. И. Мечникова (Москва, РФ) с информированного добровольного согласия участников и собраны за период с 2009 по 2017 г. Пациенты проходили аллергодиагностику с использованием коммерческих наборов RIDA (Германия). Критерии включения в исследование сывороток больных с аллергией: наличие в них $\lg \mathrm{k}$ к A. alternata или КДП D. farinae по анализу RIDA с классом 3 и более (максимум 6). Критерии исключения: пациенты, прошедшие аллергенспецифическую иммунотерапию; наличие перекрестной аллергии на $A$. alternata или КДП D. farinae. Донорами считали людей разных возрастов, у которых не были выявлены IgE к пыльцевой, бытовой или грибной панелям аллергенов.

\section{Материалы}

Для иПЦР использовали планшеты с высокой сорбирующей способностью (Costar; США), стрипованные планшеты для qiPCR Top Yield strips (ThermoFisher Scientific; США), твин-20, готовый раствор 3,3'5,5'-тетраметилбензидина (Sigma; США), козью сыворотку (Bovogen Biologicals; Австралия), биотинилированные моноклональные антитела к человеческим $\operatorname{lgG}_{1}-\operatorname{lgG}_{4}$ и $\operatorname{lgE}$ (Southern Biotech; CША), мышиные антитела $\mathrm{k} \lg \mathrm{A}_{1}, \lg \mathrm{A}_{2}$ человека, конъюгат козьих антител против IgG мыши с биотином и конъюгат стрептавидина с пероксидазой хрена (BD Pharmigen; США), биотинилированный олигодезоксирибонуклеоид (ОДН) (Lumiprobe; Москва), стрептавидин (Sigma; США). В работе использовали рекомбинантные белки rEBNA1, Der f 2 и Alt a 1, полученные ранее в нашей лаборатории [18, 2223]. Остальные реактивы - фирмы Fluka (Швейцария).

\section{Постановка иПЦР}

Раствор рекомбинантного антигена rEBNA1 (10 мкг/мл) в карбонат-бикарбонатном буфере (0,05 M, pH 9,6) вносили в лунки стрипованного планшета для иПЦР в объеме 50 мкл на лунку и инкубировали в течение ночи при $4{ }^{\circ} \mathrm{C}$. По окончании инкубации лунки промывали трижды буфером TETBS (20 мM Tris- $\mathrm{HCl}, 150 \mathrm{mM} \mathrm{NaCl,} \mathrm{0,1} \mathrm{мМ} \mathrm{ЭДТА,} \mathrm{0,1 \%}$ твин-20, рН 7,5). Образцы сывороток разбавляли в 10 раз буфером TETBS с 20\%-й козьей сывороткой, делали пятикратные серии разведений и вносили в лунки планшета в объеме 25 мкл на лунку. Каждый образец вносили в трех повторах. В качестве отрицательного контроля использовали фетальную коровью сыворотку (FBS) в 6 повторах. Планшет инкубировали на шейкере в течение 30 мин при комнатной температуре. После инкубации с образцами сывороток планшет отмывали три раза бусрером TETBS и вносили в его лунки раствор биотинилированных антител к человеческим иммуноглобулинам $\operatorname{lgG}_{1}-\operatorname{lgG}_{4}$ или мышиных антител к человеческим $\lg \mathrm{A}_{1}, \lg \mathrm{A}_{2}$ или $\operatorname{lgM}$ в TETBS с 20\%-й козьей сывороткой (1: 1000) в объеме 50 мкл на лунку. Планшеты инкубировали на шейкере в течение 30 мин при комнатной температуре и далее промывали три раза буфером TETBS. Для анализа IgA, $\lg \mathrm{A}_{2}$ или IgM планшеты далее инкубировали с конъюгатом козьих антител против IgG мыши с биотином. После отмывки в лунки планшетов вносили 50 мкл стрептавидина (1 мкг/Мл), инкубировали 10 мин, отмывали и вносили 5 пМ раствора ОДН в бусрере ТЕTВS с 20\%-й козьей сывороткой в объеме 50 мкл на лунку и инкубировали на шейкере в течение 10 мин при комнатной температуре. По окончании инкубации лунки планшета промывали 3 раза буфером TBS (20 мM Tris-HCl, 150 мM NaCl, pH 7,5). В лунки планшета вносили смесь для ПЦР в объеме 35 мкл на лунку, сверху вносили минеральное масло в объеме 30 мкл на лунку. ПЦР в реальном времени проводили на 
амплификаторе DTprime (ДНК-Технология; Россия) по следующему протоколу: начальная денатурация в течение 5 мин при $94{ }^{\circ} \mathrm{C}$ и далее 40 циклов: 15 с отжиг и элонгация при $60^{\circ} \mathrm{C}$, 5 с денатурация при $94^{\circ} \mathrm{C}$. На каждом цикле проводили измерение величины флуоресцентного сигнала от зонда при длине волны 520 нм. Результать ПЦР анализировали с использованием программного обеспечения амплификатора. Для каждого образца вычисляли среднюю величину порогового цикла $(\mathrm{Cq})$ и стандартное отклонение. Порог детекции рассчитывали как три стандартных отклонения для (Cq-), где (Cq-) величина порогового цикла в отрицательных образцах. Титр сыворотки оценивали как максимальное разведение сыворотки, при котором соответствующий образец считали положительным.

\section{Статистический анализ}

Среднее и стандартное отклонения рассчитывали с помощью программного обеспечения Excel (Microsoft Office, 2003). Корреляцию между титрами IgG1-антител и группами пациентов оценивали с помощью параметрического $X^{2}$ теста Пирсона и $t$-теста Стьюдента. Результат считали статистически значимым при значении $p<0,05$ в двустороннем анализе.

\section{РЕЗУЛЬТАТЫ ИССЛЕДОВАНИЯ}

\section{Особенности иммуно-ПЦР}

Все исследования проведены методом иПЦР (таблица). Стадии 0-3 аналогичны стадиям метода ИФА: нанесение антигена на подложку (стадия 0), инкубация с сывороткой крови (стадия 1), инкубация с биотинилированными антителами против IgG1 человека (стадия 2), инкубация со стрептавидином (ПЦР) или комплексом стрептавидин перокисидаза хрена (ИФА) (стадия 3). Стадия 3 в иПЦР разделена на две и включает инкубацию со стрептавидином, а затем дополнительную инкубацию с ОДН, что позволяет увеличить чувствительность иПЦР. На стадии 4 проводили ПЦР или добавляли субстрат для пероксидазы хрена.

Стадия детекции в ИФА с помощью субстрата не является стандартизированной и варьирует от дня постановки и времени остановки реакции блоком. При анализе иПЦР сокращается примерно на 1 ч время постановки реакции; достигается стандартное проведение анализа, не зависимое от оператора; увеличивается чувствительность за счет получения более линейных данных [18-19].

\section{Характеристика IgE-ответа на аллергены}

Для работы отобрали сыворотки больных с диагностированным с помощью коммерческой системы RIDA IgE-ответом на клещей Dermatophagoides farinae и гриб Alternaria alternata. Среди имеющейся коллекции сывороток отбирали образцы с классом выше 3. На рис. 1 представлено распределение больных по классам RIDA. B части образцов сывороток IgE-антитела не были выявлены ни к одному из 15 аллергенов трех групп (пыльцевая, бытовая и грибная). Такие сыворотки использовали в качестве донорских. Далее из имеющейся коллекции отобрали по 30 сывороток больных и доноров в возрасте 0-15 лет.

\section{Характеристика общего гуморального ответа на ВЭБ}

Для анализа профиля антител к ВЭБ у больных с респираторной аллергией на КДП и гриб A. alternata использовали пул 10 сывороток с классом 5-6, полученных от больных в возрасте 3-15 лет. В качестве контроля использовали пул сывороток 10 доноров такого же возраста. Титры антител в rEBNA1 падали в ряду IgM > $\lg G_{1}>\lg A_{1}>\lg A_{2}>g G_{2}$ (рис. 2) у доноров и в ряду $\lg M>$ $\lg A_{1}>\lg G_{1}>\lg A_{2}>\lg G_{2}$ у больных. Титры $\lg G_{3}$ и $\lg G_{4}$ были низкими в обеих группах. Достоверные различия между больными и донорами наблюдали только по уровням $\lg _{1}$ и $\lg \mathrm{A}_{1}$. Отношение титров $\lg _{1} \mathrm{k} \lg \mathrm{A}_{1}$ для доноров и больных составило 9 и 0,4 соответственно, что показывает доминирование IgA ответа у больных с аллергией и $\operatorname{lgG}_{1}$ у здоровых доноров.

\section{Анализ IgG 1 ответа на ВЭБ}

При вирусных инфекциях в основном вырабатываются антитела класса $\operatorname{lgG}_{1}$. На рис. ЗА представлено распределение титров $\operatorname{lgG}_{1}$ к ВЭБ в сыворотках больных с аллергией (сыворотки с аллергией на КДП и/или A. alternata) и доноров в зависимости от возраста. Показано, что инфицирование возникает в раннем возрасте в обеих группах. У некоторых 4-6-летних детей в обеих группах выявлялись титры $\operatorname{lgG}_{1}>1000$. Средний титр $\lg G_{1}$ в группе пациентов в возрасте 3-10 лет у больных и доноров составил 330 и 1500 соответственно, в возрасте 11-20 лет - 720 и 490, что показывает тенденцию к более ранней инфицированности/реактивности доноров. Из-за значительного разброса данных достоверных различий между группами не было. Не было также различий по уровню антител к ВЭБ между больными аллергией на КДП, гриб A. alternata и донорами (рис. ЗБ).

Анализ доли индивидов, не имеющих антител к ВЭБ, имеющих низкие (< 100), средние (100-1000) и высокие

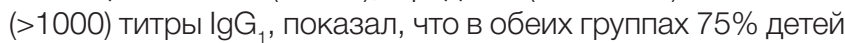
в возрасте 3-15 лет являются латентными носителями ВЭБ (рис. 4A); у 45\% индивидов в обеих группах выявлялись антитела с низкими титрами. Различия наблюдались между группами по продукции антител с высокими титрами: 20\% доноров имели титры антител больше 1000 (20008000); у больных с аллергией таких детей было только 7\% (рис. 4А), что показывает большую резистентность к инфекции при аллергии. При этом титры антител к ВЭБ в соответствующих группах были близкими (рис 4Б).

Таблица. Схема постановки и ПЦР в сравнении с иммуноферментным анализом (ИФА)

\begin{tabular}{|c|c|c|c|c|c|c|}
\hline Стадии & 0 & 1 & 2 & 3 & 4 & \\
\hline ПЦР & Антиген & Сыворотка & algG1-biо* & Стрептавидин/ОДН & ПЦР & Время \\
\hline & Ночь & 30 мин & 30 мин & $10 / 10$ мин & 14 & $3-4$ ч \\
\hline ИФА & Антиген & Сыворотка & algG1-bio & Стрептавидин-ПХ** & Субстрат & \\
\hline & Ночь & 14 & 14 & 14 & 20 мин & $4-54$ \\
\hline
\end{tabular}

Примечание: * - algG1-bio - битинилированное антитело к любому классу или субклассу антител (G, A, E); **ПX — пероксидаза хрена. 
Анализ $\lg \mathrm{A}_{1}$ - и $\lg$ М-ответов на ВЭБ

Выше было показано, что у больных с аллергией незначительно, но достоверно повышены антитела класса $A_{1}(p=0,03)$. Более детальный анализ показал, что основное различие наблюдается на ранней стадии инфиццирования (рис. 5А). Средние титры IgA, к ВЭБ у больных и доноров в возрасте 3-10 лет составили 425 и 265, в возрасте 11-30 лет - 690 и 370 соответственно. В обеих группах наблюдали рост титров антител с возрастом (рис. 5A). Интересно, что по титрам IgA, к ВЭБ наблюдали разницу между больными с разным типом сенсибилизирующего аллергена. Титры IgA к ВЭБ были достоверно выше при аллергии на КДП (рис. 5Б), чем у больных с IgE к A. alternata и доноров.

Средние титры IgM к ВЭБ на порядок превышали титры иммуноглобулинов классов $\mathrm{G}$ и А в сыворотках как доноров, так и больных. Индивидуальные данные разбивали на низкие (< 5000) и высокие (> 15 000) титры (рис. 5В, Г). Доля высокотитровых по IgM индивидуумов в

A

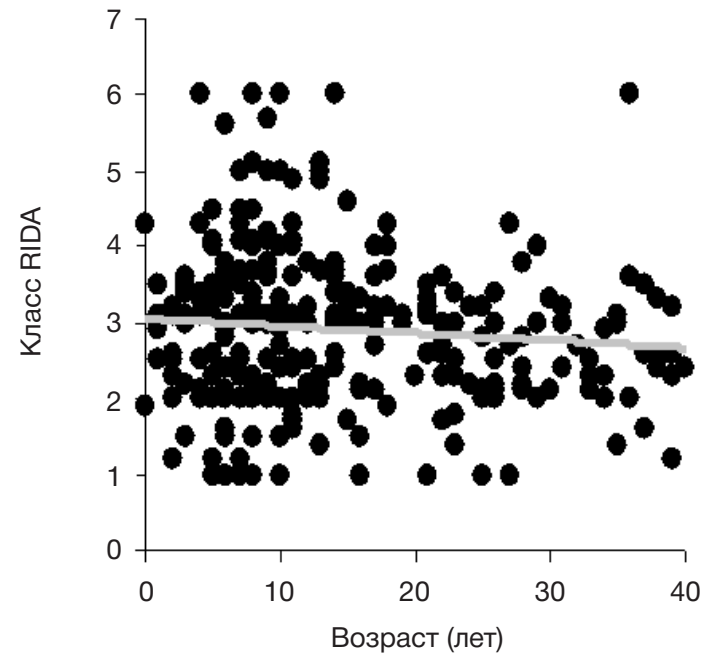

обеих группах составила 60\%. В этой группе не наблюдали различий в изменении титров $\operatorname{lgM}$ в зависимости от возраста и среднего титра (рис. 5В). В группе с низкими титрами lgM у больных с аллергией антитела появлялись раньше, чем у доноров (рис. 5В) и средние титры были выше (рис. 5Г). Повышение титров IgM в этой группе наблюдали при аллергии как на КДП, так и на гриб A. alternata (рис. 5Г).

\section{ОБСУЖДЕНИЕ РЕЗУЛЬТАТОВ}

В процессе естественного инфицирования ВЭБ формируются антитела разных классов и субклассов. У человека имеются антитела классов М, A, G и E, включающие субклассы $\operatorname{lgG}_{1}-\lg G_{4}$ и $\lg A_{1}-\lg A_{2}$. Основной пул антител М-класса относится $\mathrm{K}$ врожденному иммунитету и их титры повышаются при первичном инфицировании; IgA обеспечивают защиту слизистых оболочек; IgE повышаются при паразитарных инфекциях и аллергии. В настоящее время считается, что IgA и IgE

\section{5}

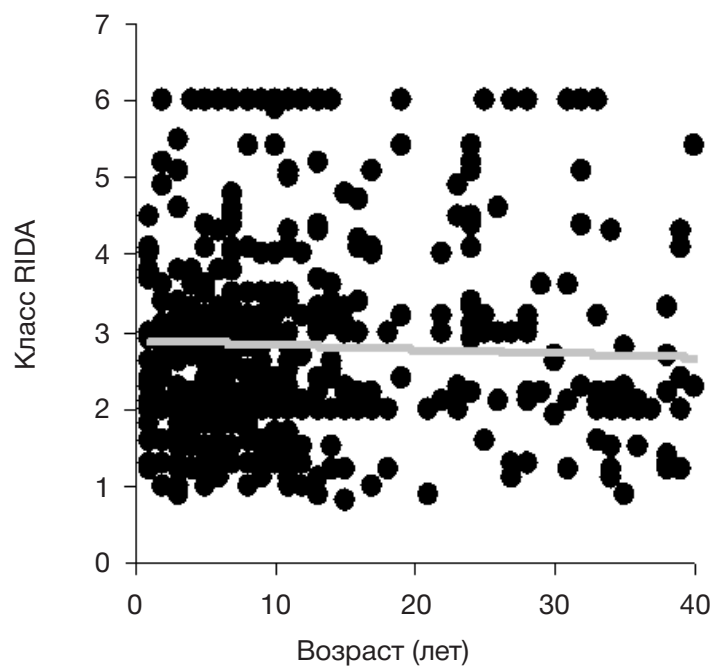

Рис. 1. Характеристика IgE ответа у больных с аллергией методом RIDA. Уровень IgE в сыворотках пациентов с аллергией на клещей домашней пыли (A) и гриб A. alternata (Б) оценивается в классах от 0 до 6, что пропорционально титрам IgE

A

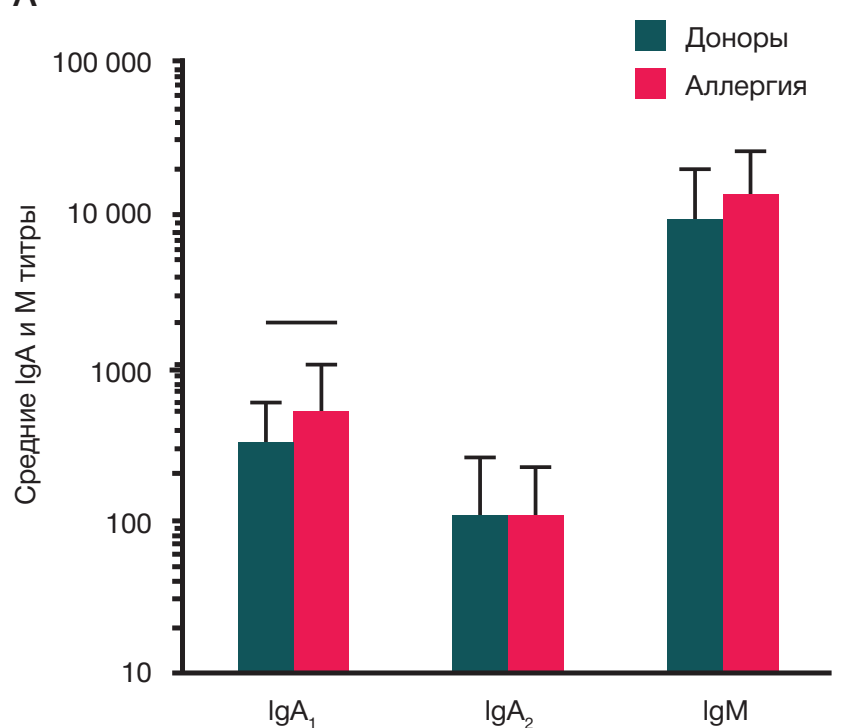

Б

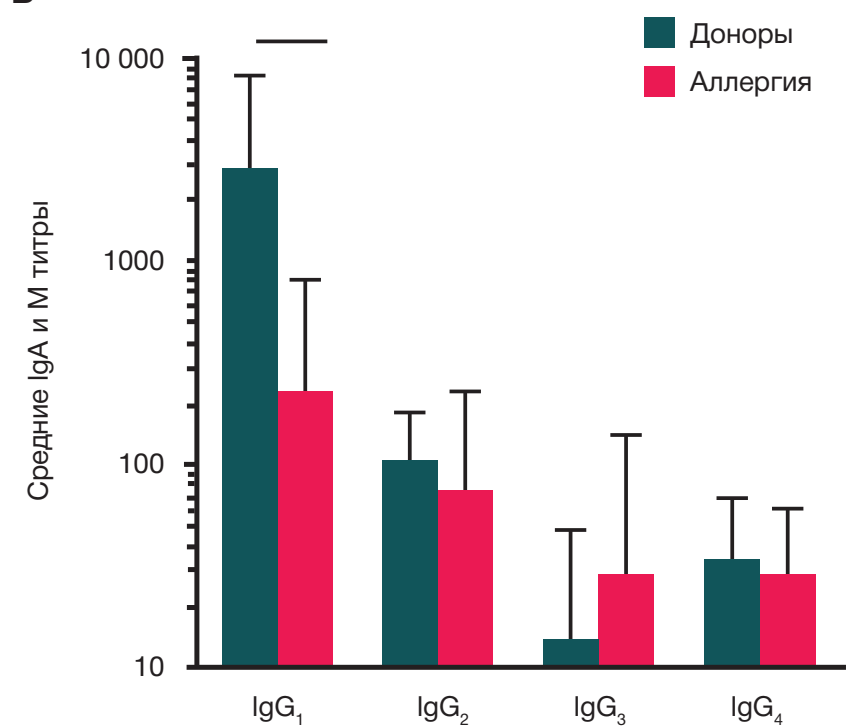

Рис. 2. Анализ иммуноглобулинов, распознающих rEBNA1, в сыворотках здоровых доноров и пациентов с аллергией. Анализ $\lg \mathrm{A}_{1}$, $\lg \mathrm{A}_{2}$, $\lg M(\mathrm{~A})$, $\lg \mathrm{G}_{1}, \lg \mathrm{G}_{2}$, $\lg _{3}$ и $\operatorname{lgG}_{4}$ (Б) в пулированных сыворотках 10 доноров и 10 пациентов. Приведены средние значения \pm стандартное отклонение. Планками отмечены достоверные $(p<0,05)$ различия 
относятся к адаптивному иммунитету, поскольку для этого требуется переключение В-клеток c IgM на другие субклассы. Однако в последнее время ставится вопрос локального переключения В-клеток на синтез IgA- и IgEантител без участия Т-клеток [23, 24], что соответствует функционированию врожденного иммунитета. Антитела A-класса обычно относят к ранним антигенам VCA и EA [25]. Антитела классов М и А к ранним антигенам служат маркерами реактивации вируса или вторичного заражения. Антитела А-класса к позднему антигену ВЭБ ЕBNA1 также выявляются и значительно повышаются, например, при раке носоглотки [26].

Полученные нами данные показывают, что у больных с аллергическими реакциями в более ранний срок и в более высоких титрах повышаются титры IgA - и IgMантител. При этом титры IgA были ниже, чем титры IgA и не различались между группами (данные не показаны). При аллергической реакции наблюдается воспалительная реакция в слизистых оболочках, повышается продукция

A

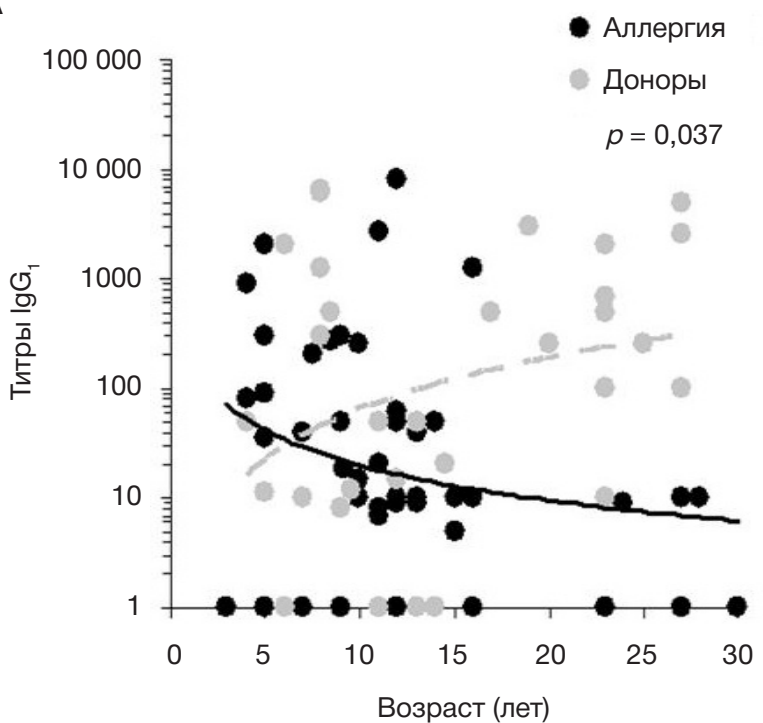

цитокинов и хемокинов $[17,24]$, что способствует активации В-клеток. В случае высокотитровых сывороток продукция IgM в группах доноров и больных была сравнимой, что показывает равную эффективность иммунного ответа при реактивации вирусом В-клеток, синтезирующих IgM.

Основным протективным звеном адаптивного гуморального ответа являются IgG. Переключение В-клеток на синтез IgG происходит только при формировании антиген-специфичного Т-зависимого ответа на ВЭБ. Известно, что при противовирусном ответе доминирует IgG -ответ [27-28]. По литературным данным, при ответе на вирус гепатита В титры антител падают в ряду $\lg _{1}>\lg _{4}>\lg _{3}>\lg G_{2}$ [27], при ответе на ВЭБ $\operatorname{lgG}_{1}>>\operatorname{lgG}_{2}, \operatorname{lgG}_{3}, \operatorname{lgG}_{4}$ [28]. Полученные нами данные для доноров характерны для ответа на ВЭБ с доминированием $\lg _{1}$. Для больных с аллергией средний уровень lgG был ниже, чем в группе доноров, и сравним с уровнем $\operatorname{lgG}_{2}(p=0,14)$. Статистический анализ данных

Б

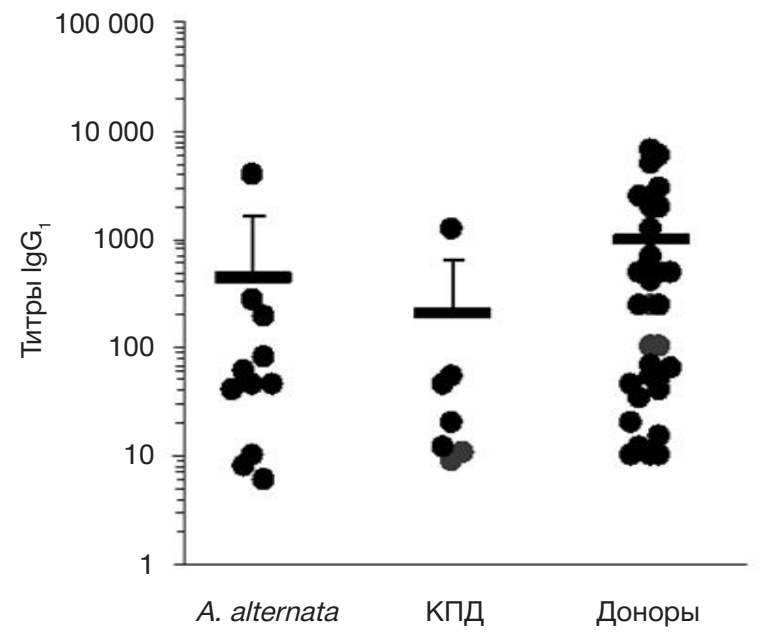

Рис. 3. Анализ rEBNA1 специфичных $\lg G_{1}$ в сыворотках здоровых доноров и пациентов с аллергией. А. Анализ титров IgG 1 в индивидуальных сыворотках пациентов с аллергией на гриб A. alternata $(n=15)$, клещей домашней пыли $(n=9)$ и доноров $(n=38)$. Планками показаны средние значения \pm стандартное отклонение. Б. Зависимость титров rEBNA1 специфичных IgG1 от возраста в индивидуальных сыворотках пациентов с аллергией ( $n=53)$ и доноров $(n=34)$. Аппроксимация степенной функцией показана линиями

A

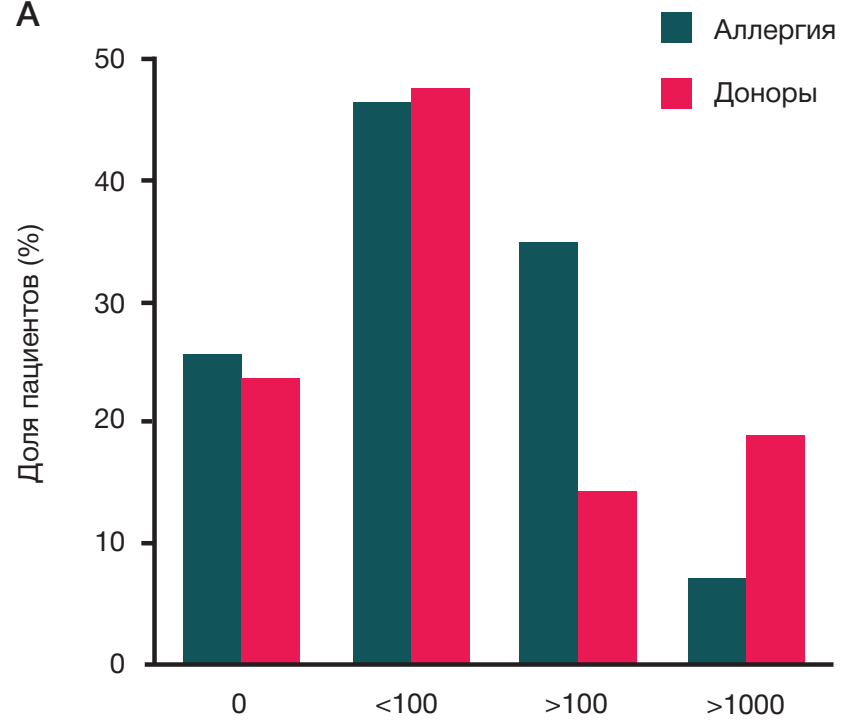

Б

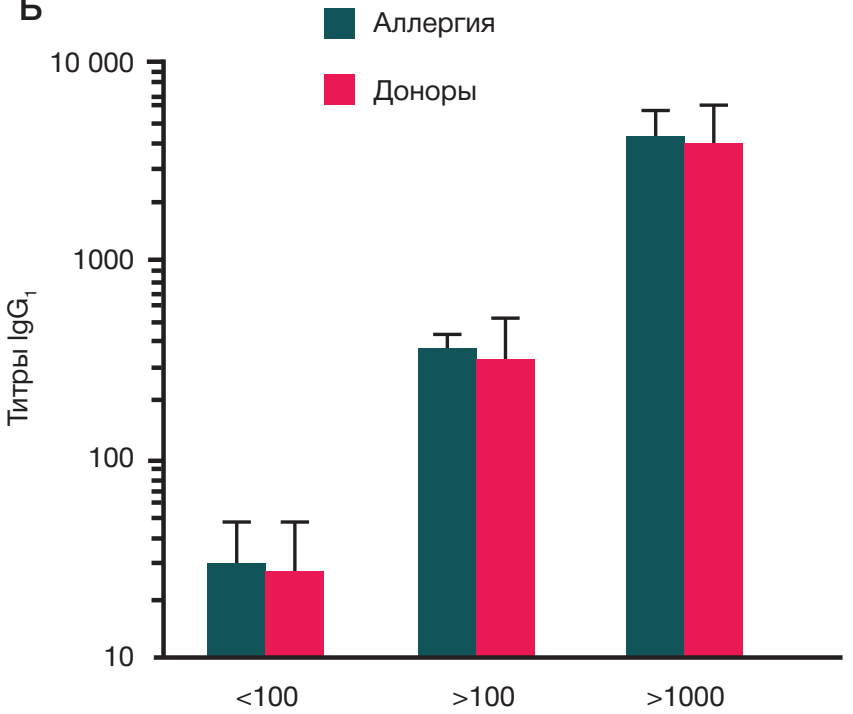

Рис. 4. Анализ репертуара rEBNA1 специфичных IgG в сыворотках здоровых доноров и пациентов с аллергией. Доля (\%) пациентов и доноров, у которых выявлены $\lg \mathrm{G}_{1}$ с различными титрами (А), и средние титры в этих группах (Б) 
A

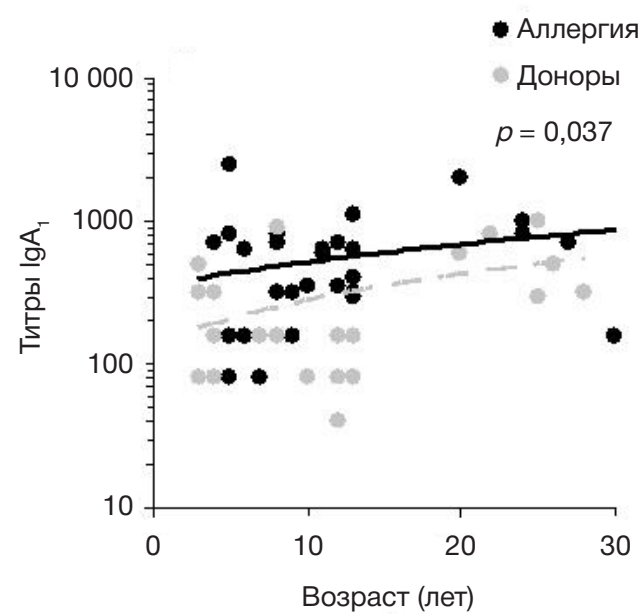

Б

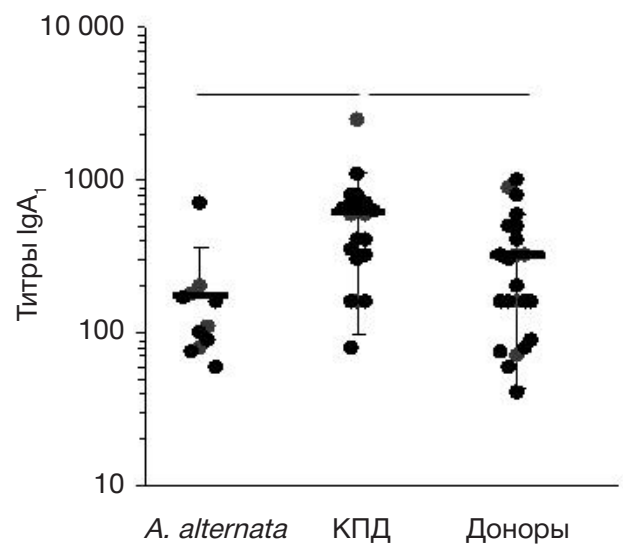

B

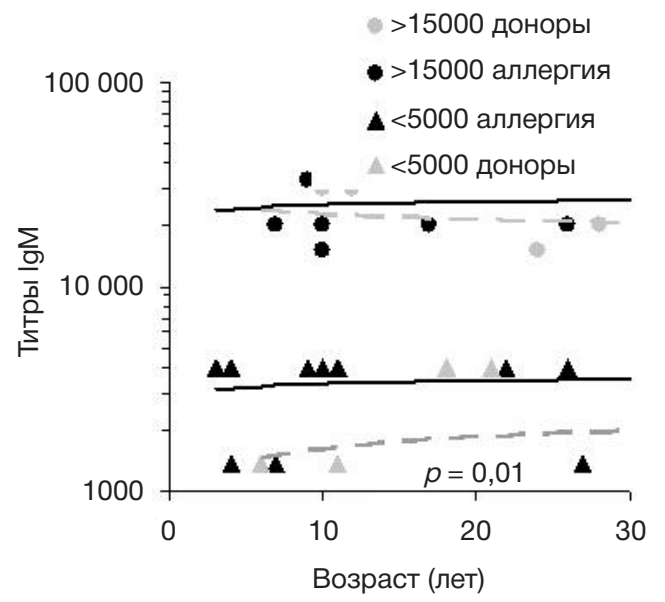

$\Gamma$

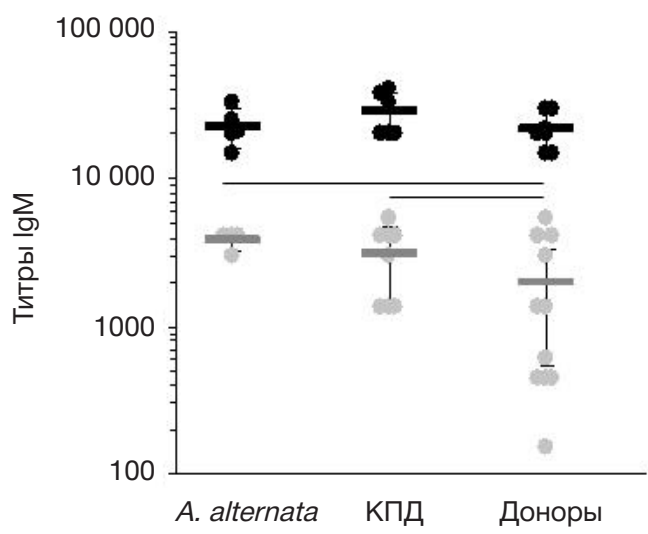

Рис. 5. Анализ rEBNA1 специсичных IgA, и IgM в сыворотках здоровых доноров и пациентов с аллергией. Анализ титров IgA, (А) и IgM (В) в индивидуальных сыворотках пациентов с аллергией на гриб A. alternata $(n=11)$, клещей домашней пыли $(n=21)$ и доноров $(n=23)$ в зависимости от возраста. Распределение титров rEBNA1 специфичных IgA $($ (Б) и IgM (Г) в сыворотках пациентов с аллергией и здоровых доноров. Данные по IgM представлены для сывороток с низкими (серые кружки) и высокими (черные кружки) титрами антител IgМ. Планками показаны средние значения \pm стандартное отклонение. Верхними планками показаны достоверные отличия $(p<0,05)$

показал, что достоверные различия между больными с аллергией и донорами по титрам IgG, возрастают с возрастом. Ранее противовирусный ответ у больных с аллергией не изучали. В целом, полученные данные позволяют предположить, что при респираторной аллергии можно наблюдать повышение количества IgA - $_{1}$ IgM-антител к ВЭБ, что снижает его проникновение через эпителиальные барьеры и уменьшает общую вирусную нагрузку.

\section{Литература}

1. Kayamba V, Monze M, Asombang AW, Zyambo K, Kelly P. Serological response to Epstein-Barr virus early antigen is associated with gastric cancer and human immunodeficiency virus infection in Zambian adults: a case-control study. Pan Afr Med J. 2016; (23): 45. DOI: 10.11604/pamj.2016.23.45.8503.

2. Banko AV, Lazarevic IB, Folic MM, Djukic VB, Cirkovic AM, Karalic DZ, Cupic MD, Jovanovic TP. Characterization of the Variability of Epstein-Barr Virus Genes in Nasopharyngeal Biopsies: Potential Predictors for Carcinoma Progression. PLoS One. 2016; 11 (4): e0153498. DOI: 10.1371/journal.pone.0153498.

3. Frappier L. EBNA1. Curr Top Microbiol Immunol. 2015; (391): 3-34. DOI: 10.1007/978-3-319-22834-1_1.

4. Myhr KM, Riise T, Barrett-Connor E, Myrmel H, Vedeler C, Grønning M, Kalvenes MB, Nyland $\mathrm{H}$. Altered antibody pattern to Epstein-Barr virus but not to other herpesviruses in multiple

\section{ВЫВОДЫ}

Аллергия характеризуется повышенной реактивностью эпителиальных барьеров, что вызвано взаимодействием $\mathrm{IgE}$ с аллергенами. Повышение реактивности врожденной системы иммунитета, по-видимому, приводит к повышению противовирусного ответа на вирус Эпштейна-Барр, повышению титров $\lg \mathrm{A}_{1}$ и $\lg \mathrm{M}$, снижению титров $\lg _{1}$, коррелирующих с латентной вирусной нагрузкой. sclerosis: a population based case-control study from western Norway. J Neurol Neurosurg Psychiatry. 1998; 64 (4): 539-42.

5. Lomakin Y, Arapidi GP, Chernov A, Ziganshin R, Tcyganov E, Lyadova I, Butenko IO, Osetrova M, Ponomarenko N, Telegin G, Govorun VM, Gabibov A, Belogurov A Jr. Exposure to the Epstein-Barr Viral Antigen Latent Membrane Protein 1 Induces Myelin-Reactive Antibodies In Vivo. Front Immunol. 2017; (8): 777. DOI: 10.3389/fimmu.2017.00777.

6. Piroozmand A, Haddad Kashani H, Zamani B. Correlation between Epstein-Barr Virus Infection and Disease Activity of Systemic Lupus Erythematosus: a Cross-Sectional Study. Asian Pac J Cancer Prev. 2017; (18): 523-7.

7. Pan R, Liu X, Zhou S, Ning Z, Zheng H, Gao M, Ding Y, Yao W, Liao X, He N. Differential prevalence and correlates of whole blood Epstein-Barr virus DNA between HIV-positive and HIV-negative 
men who have sex with men in Shanghai, China. Epidemiol Infect. 2017; 145 (11): 2330-40. DOI: 10.1017/S0950268817001054.

8. Lindsey JW, deGannes SL, Pate KA, Zhao X. Antibodies specific for Epstein-Barr virus nuclear antigen-1 cross-react with human heterogeneous nuclear ribonucleoprotein L. Mol Immunol. 2016 Jan; (69): 7-12. DOI: 10.1016/j.molimm.2015.11.007.

9. Lindsey JW. Antibodies to the Epstein-Barr virus proteins BFRF3 and BRRF2 cross-react with human proteins. Neuroimmunol. 2017; (310): 131-4.

10. Al Sidairi H, Binkhamis K, Jackson C, Roberts C, Heinstein C, MacDonald J, Needle R, Hatchette TF, LeBlanc JJ. Comparison of two automated instruments for Epstein-Barr virus serology in a large adult hospital and implementation of an Epstein-Barr virus nuclear antigen-based testing algorithm. J Med Microbiol. 2017; 66 (11): 1628-34. DOI: 10.1099/jmm.0.000616.

11. Maylin S, Feghoul L, Salmona M, Herda A, Mercier-Delarue S, Simon F, Legoff J. Evaluation the Architect EBV VCA IgM, VCA IgG, and EBNA-1 IgG chemiluminescent immunoassays to assess EBV serostatus prior transplantation. J Med Virol. 2017; 89 (11): 2003-10. DOI: 10.1002/jmv.24889.

12. Simon KC, Saghafian-Hedengren $S$, Sverremark-Ekström E, Nilsson C, Ascherio A. Age at Epstein-Barr virus infection and Epstein-Barr virus nuclear antigen-1 antibodies in Swedish children. Mult Scler Relat Disord. 2012; 1 (3): 136-8. DOl: 10.1016/j.msard.2012.03.002.

13. Xiong G, Zhang B, Huang MY, Zhou H, Chen LZ, Feng QS, Luo X, Lin HJ, Zeng YX. Epstein-Barr virus (EBV) infection in Chinese children: a retrospective study of age-specific prevalence. PLoS One. 2014; 9 (6): e99857. DOI: 10.1371/journal.pone.0099857.

14. Feng $\mathrm{C}, \mathrm{Kim} \mathrm{JH}$. Beyond Avoidance: the Psychosocial Impact of Food Allergies. Clin Rev Allergy Immunol. 2018. DOI: 10.1007/ s12016-018-8708-X

15. Licari A, Castagnoli R, Brambilla I, Marseglia A, Tosca MA, Marseglia GL, Ciprandi G. Asthma Endotyping and Biomarkers in Childhood Asthma. Pediatr Allergy Immunol Pulmonol. 2018; 31 (2): 44-55. DOI: 10.1089/ped.2018.0886.

16. Tsakok T, Woolf $\mathrm{R}$, Smith $\mathrm{CH}$, Weidinger S, Flohr C. Atopic dermatitis: the skin barrier and beyond. Br J Dermatol. 2018. DOI: 10.1111/bjd.16934.

17. Carsin A, Mazenq J, Ilstad A, Dubus JC, Chanez P, Gras D. Bronchial epithelium in children: a key player in asthma. Eur Respir Rev. 2016; 25 (140): 158-69. DOl: 10.1183/16000617.0101-2015.

18. Пивоваров В. Д., Рязанцев Д. Ю., Симонова М. А.,
Димитриева Т. В., Хлгатян С. В., Завриев С. К., Свирщевская Е. В. Разработка тест-системы для анализа антител к вирусу Эпштейна-Барр методом иммуно-ПЦР. Молекулярная биология. 2018; 52 (4): 727-34.

19. Simonova MA, Pivovarov VD, Ryazantsev DY, Dolgova AS, Berzhets VM, Zavriev SK, Svirshchevskaya EV. Comparative diagnostics of allergy using quantitative immuno-PCR and ELISA. Bioanalysis. 2018. DOI: 10.4155/bio-2017-0194.

20. Chang L, Li J, Wang L. Immuno-PCR: An ultrasensitive immunoassay for biomolecular detection. Anal Chim Acta. 2016; (910): 12-24. DOl:10.1016/j.aca.2015.12.039.

21. Jani D, Savino E, Goyal J. Feasibility of immuno-PCR technology platforms as an ultrasensitive tool for the detection of anti-drug antibodies. Bioanalysis. 2015; (7): 285-94.

22. Рязанцев Д. Ю., Дробязина П. Е., Хлгатян С. В., Завриев С. К., Свирщевская Е. В. Экспрессия аллергенов клещей домашней пыли Der f 1 и Der f 2 в листьях Nicotiana benthamiana. Биоорганическая химия. 2014; 40 (4): 468-78.

23. Svirshchevskaya E, Fattakhova G, Khlgatian S, Chudakov D, Kashirina E, Ryazantsev D, Kotsareva O, Zavriev S. Direct versus sequential immunoglobulin switch in allergy and antiviral responses. Clin Immunol. 2016; (170): 31-8. DOI: 10.1016/j. clim.2016.07.022.

24. Takaki H, Ichimiya S, Matsumoto M, Seya T. Mucosal Immune Response in Nasal-Associated Lymphoid Tissue upon Intranasal Administration by Adjuvants. J Innate Immun. 2018; (10): 515-21. DOI: 10.1159/000489405.

25. Bhaduri-McIntosh $S$, Landry ML, Nikiforow S, Rotenberg $M$, El-Guindy A, Miller G. Serum IgA antibodies to Epstein-Barr virus (EBV) early lytic antigens are present in primary EBV infection. J Infect Dis. 2007; 195 (4): 483-92.

26. Cai YL, Li J, Lu AY, Zheng YM, Zhong WM, Wang W, Gao JQ, Zeng H, Cheng JR, Tang MZ. Diagnostic significance of combined detection of Epstein-Barr virus antibodies, VCA/lgA, EA/lgA, Rta/ IgG and EBNA1/IgA for nasopharyngeal carcinoma. Asian Pac $J$ Cancer Prev. 2014; 15 (5): 2001-6.

27. Wang L, Tsai TH, Huang CF, Ho MS, Lin DB, Ho YC, Lin SS, Wei JC, Chou MC, Yang CC. Utilizing self-prepared ELISA plates for a cross-population study of different anti-HBe lgG subclass profiles. J Med Virol. 2007; 79 (5): 495-2.

28. Wakiguchi H, Hisakawa H, Hosokawa T, Kubota H, Kurashige T. Analysis of lgG subclasses in chronic active Epstein-Barr virus infection. Pediatr Int. 2000; 42 (1): 21-5.

\section{References}

1. Kayamba V, Monze M, Asombang AW, Zyambo K, Kelly P. Serological response to Epstein-Barr virus early antigen is associated with gastric cancer and human immunodeficiency virus infection in Zambian adults: a case-control study. Pan Afr Med J. 2016; (23): 45. DOI: 10.11604/pamj.2016.23.45.8503.

2. Banko AV, Lazarevic IB, Folic MM, Djukic VB, Cirkovic AM, Karalic DZ, Cupic MD, Jovanovic TP. Characterization of the Variability of Epstein-Barr Virus Genes in Nasopharyngeal Biopsies: Potential Predictors for Carcinoma Progression. PLoS One. 2016; 11 (4): e0153498. DOI: 10.1371/journal.pone.0153498.

3. Frappier L. EBNA1. Curr Top Microbiol Immunol. 2015; (391): 3-34. DOI: 10.1007/978-3-319-22834-1_1.

4. Myhr KM, Riise T, Barrett-Connor E, Myrmel H, Vedeler $\mathrm{C}$, Grønning M, Kalvenes MB, Nyland $\mathrm{H}$. Altered antibody pattern to Epstein-Barr virus but not to other herpesviruses in multiple sclerosis: a population based case-control study from western Norway. J Neurol Neurosurg Psychiatry. 1998; 64 (4): 539-42.

5. Lomakin Y, Arapidi GP, Chernov A, Ziganshin R, Tcyganov E, Lyadova I, Butenko IO, Osetrova M, Ponomarenko N, Telegin G, Govorun VM, Gabibov A, Belogurov A Jr. Exposure to the Epstein-Barr Viral Antigen Latent Membrane Protein 1 Induces Myelin-Reactive Antibodies In Vivo. Front Immunol. 2017; (8): 777. DOI: 10.3389/fimmu.2017.00777.

6. Piroozmand A, Haddad Kashani H, Zamani B. Correlation between Epstein-Barr Virus Infection and Disease Activity of Systemic Lupus Erythematosus: a Cross-Sectional Study. Asian Pac J Cancer Prev. 2017; (18): 523-7.

7. Pan R, Liu X, Zhou S, Ning Z, Zheng H, Gao M, Ding Y, Yao W, Liao X, He N. Differential prevalence and correlates of whole blood Epstein-Barr virus DNA between HIV-positive and HIV-negative men who have sex with men in Shanghai, China. Epidemiol Infect. 2017; 145 (11): 2330-40. DOI: 10.1017/S0950268817001054.

8. Lindsey JW, deGannes SL, Pate KA, Zhao X. Antibodies specific for Epstein-Barr virus nuclear antigen-1 cross-react with human heterogeneous nuclear ribonucleoprotein L. Mol Immunol. 2016 Jan; (69): 7-12. DOI: 10.1016/.j.molimm.2015.11.007.

9. Lindsey JW. Antibodies to the Epstein-Barr virus proteins BFRF3 and BRRF2 cross-react with human proteins. Neuroimmunol. 2017; (310): 131-4.

10. Al Sidairi H, Binkhamis K, Jackson C, Roberts C, Heinstein C, MacDonald J, Needle R, Hatchette TF, LeBlanc JJ. Comparison of two automated instruments for Epstein-Barr virus serology in a large adult hospital and implementation of an Epstein-Barr virus nuclear antigen-based testing algorithm. J Med Microbiol. 2017; 66 (11): 1628-34. DOI: 10.1099//mm.0.000616.

11. Maylin S, Feghoul L, Salmona M, Herda A, Mercier-Delarue S, Simon F, Legoff J. Evaluation the Architect EBV VCA IgM, VCA IgG, and EBNA-1 IgG chemiluminescent immunoassays to 
assess EBV serostatus prior transplantation. J Med Virol. 2017; 89 (11): 2003-10. DOI: 10.1002/jmv.24889.

12. Simon KC, Saghafian-Hedengren $S$, Sverremark-Ekström $E$, Nilsson C, Ascherio A. Age at Epstein-Barr virus infection and Epstein-Barr virus nuclear antigen-1 antibodies in Swedish children. Mult Scler Relat Disord. 2012; 1 (3): 136-8. DOI: 10.1016/j.msard.2012.03.002.

13. Xiong G, Zhang B, Huang MY, Zhou H, Chen LZ, Feng QS, Luo X, Lin HJ, Zeng YX. Epstein-Barr virus (EBV) infection in Chinese children: a retrospective study of age-specific prevalence. PLoS One. 2014; 9 (6): e99857. DOI: 10.1371/journal.pone.0099857.

14. Feng $\mathrm{C}, \mathrm{Kim} \mathrm{JH}$. Beyond Avoidance: the Psychosocial Impact of Food Allergies. Clin Rev Allergy Immunol. 2018. DOI: 10.1007/ s12016-018-8708-X.

15. Licari A, Castagnoli R, Brambilla I, Marseglia A, Tosca MA, Marseglia GL, Ciprandi G. Asthma Endotyping and Biomarkers in Childhood Asthma. Pediatr Allergy Immunol Pulmonol. 2018; 31 (2): 44-55. DOI: 10.1089/ped.2018.0886.

16. Tsakok T, Woolf R, Smith $\mathrm{CH}$, Weidinger S, Flohr C. Atopic dermatitis: the skin barrier and beyond. Br J Dermatol. 2018. DOI: 10.1111/bjd.16934.

17. Carsin A, Mazenq J, Ilstad A, Dubus JC, Chanez P, Gras D. Bronchial epithelium in children: a key player in asthma. Eur Respir Rev. 2016; 25 (140): 158-69. DOI: 10.1183/16000617.01012015.

18. Pivovarov VD, Ryazantsev DYu, Simonova MA, Dimitrieva TV, Khlgatian SV, Zavriev SK, Svirshchevskaya EV. Razrabotka testsistemy dlja analiza antitel $\mathrm{k}$ virusu Jepshtejna-Barr metodom immuno-PCR. Molekuljarnaja biologija. 2018; 52 (4): 727-34.

19. Simonova MA, Pivovarov VD, Ryazantsev DY, Dolgova AS, Berzhets VM, Zavriev SK, Svirshchevskaya EV. Comparative diagnostics of allergy using quantitative immuno-PCR and ELISA. Bioanalysis. 2018. DOI: 10.4155/bio-2017-0194.

20. Chang L, Li J, Wang L. Immuno-PCR: An ultrasensitive immunoassay for biomolecular detection. Anal Chim Acta. 2016; (910): 12-24. DOl:10.1016/j.aca.2015.12.039.

21. Jani $D$, Savino E, Goyal J. Feasibility of immuno-PCR technology platforms as an ultrasensitive tool for the detection of anti-drug antibodies. Bioanalysis. 2015; (7): 285-94.

22. Ryazantsev DYu, Drobyazina PE, Khlgatian SV, Zavriev SK, Svirshchevskaya EV. Jekspressija allergenov kleshhej domashnej pyli Der f 1 i Der f 2 v list'jah Nicotiana benthamiana. Bioorganicheskaja himija. 2014; 40 (4): 468-78.

23. Svirshchevskaya E, Fattakhova G, Khlgatian S, Chudakov D, Kashirina E, Ryazantsev D, Kotsareva O, Zavriev S. Direct versus sequential immunoglobulin switch in allergy and antiviral responses. Clin Immunol. 2016; (170): 31-8. DOI: 10.1016/j. clim.2016.07.022.

24. Takaki H, Ichimiya S, Matsumoto M, Seya T. Mucosal Immune Response in Nasal-Associated Lymphoid Tissue upon Intranasal Administration by Adjuvants. J Innate Immun. 2018; (10): 515-21. DOI: 10.1159/000489405.

25. Bhaduri-Mclntosh $S$, Landry ML, Nikiforow $S$, Rotenberg $M$, El-Guindy A, Miller G. Serum IgA antibodies to Epstein-Barr virus (EBV) early lytic antigens are present in primary EBV infection. J Infect Dis. 2007; 195 (4): 483-92.

26. Cai YL, Li J, Lu AY, Zheng YM, Zhong WM, Wang W, Gao JQ, Zeng H, Cheng JR, Tang MZ. Diagnostic significance of combined detection of Epstein-Barr virus antibodies, VCA/lgA, EA/lgA, Rta/ IgG and EBNA1/lgA for nasopharyngeal carcinoma. Asian Pac $J$ Cancer Prev. 2014; 15 (5): 2001-6.

27. Wang L, Tsai TH, Huang CF, Ho MS, Lin DB, Ho YC, Lin SS, Wei JC, Chou MC, Yang CC. Utilizing self-prepared ELISA plates for a cross-population study of different anti-HBe IgG subclass profiles. J Med Virol. 2007; 79 (5): 495-2.

28. Wakiguchi $\mathrm{H}$, Hisakawa $\mathrm{H}$, Hosokawa T, Kubota H, Kurashige T. Analysis of IgG subclasses in chronic active Epstein-Barr virus infection. Pediatr Int. 2000; 42 (1): 21-5. 